\section{Selection Preferences for Crabapple Cultivars and Species}

\author{
James P. Romer, ${ }^{1}$ \\ Jeffery K. Iles, ${ }^{2}$ and \\ Cynthia L. Haynes ${ }^{3}$
}

Additional index Words. Malus, survey, questionnaire, regional preferences, ornamental trees

Summary. Crabapples (Malus spp.) are commonly planted ornamental trees in public and private landscapes. Hundreds of selections are available that represent a wide range of growth habits, ornamental traits, and varying degrees of resistance/susceptibility to disease. We distributed 1810 questionnaires in 13 states (Oregon, Washington, Utah, Colorado, Minnesota, Iowa, Missouri, Illinois, Indiana, Michigan, Ohio, New York, and Pennsylvania) to members of either nursery and landscape associations or the Associated Landscape Contractors of America (ACLA, Herndon, Va.) to identify crabapple preferences across a broad geographic region of the United States. We also were interested in learning if regional disease problems were important to green-industry professionals as they decide which crabapples to include in their inventories. Our respondent population numbered 511 (28.2\% response rate). A large percentage of respondents $(79.4 \%)$ said their retail clients focused mostly on flower color when choosing crabapples for the home landscape, while commercial clients showed slightly more interest in growth habit $(32.5 \%)$ than flower color $(28.7 \%)$. 'Prairifire' was identified by respondents in all regions, except the west-central (Colorado and Utah), as the crabapple most frequently recommended to clients when tree size is not important. Respondents in the west-central region most often $(48.7 \%)$ recommend the fruitless selection 'Spring Snow'.

\footnotetext{
Iowa State University, Department of Horticulture, 106 Horticulture Hall, Ames, IA 50011-1100.

This journal paper of the Iowa Agriculture and Home Economics Experiment Station, Ames, Project 3606 was supported by hatch Act and the State of Iowa.

${ }^{1}$ Extension program specialist.

${ }^{2}$ Associate professor.
}

${ }^{3}$ Assistant professor.
Respondents in all regions, except the west-central, identified apple scab (Venturia inaequalis) as the most prevalent crabapple disease and named scab-susceptible 'Radiant' as the selection most frequently discontinued.

C rabapples are the most widely cultivated small landscape tree in the northern United States and southern Canada (Brewer et al., 1979; Draper et al., 1996; Guthery and Hasselkus, 1992). Hamilton (1986) surveyed members of the National Landscape Association (Washington, D.C.) and found crabapples the most popular flowering tree in 1956, 1970, 1976, and 1982. Unfortunately, specific selections were not identified.

As popular as they are, several issues pertaining to crabapples have strained the relationship between nursery and landscape professionals and their clients. For instance, the sheer number of available crabapple selections has created confusion and skepticism over the quality and uniqueness of individual taxa (Iles and Stookey, 1997). Fiala (1994) describes several hundred named selections, but candidly admits that 60 to $70 \%$ of them have proven less than desirable and should never have been introduced. In addition, selections having poor disease resistance (e.g., 'Radiant' and 'Royalty') and/or undesirable fruit litter ('Hopa') have damaged the reputation of the entire genus (Fiala, 1994).

In 1983, the National Crabapple Evaluation Program was established (Nichols, 1985). This innovative program expanded crabapple evaluation over a broader geographic range and helped quantify crabapple desirability based on the aesthetics and diseaseresistance of actual plantings.

Working concurrently, Smith (1979) and Smith and Treaster (1989, $1990,1991)$ performed annual crabapple evaluations at the Secrest Arboretum in Wooster, Ohio. Of the 150 cultivars and species they evaluated, 74 demonstrated varying resistance to the fungal pathogen responsible for apple scab. Their data, while useful and appropriate for Ohio and adjacent midwestern states, may not be a reliable indicator of crabapple performance in regions where environmental conditions are dramatically different.

Iles and Stookey (1997) sur- veyed members of the Iowa Nursery and Landscape Association to assess the importance of crabapples to the nursery and landscape industry in Iowa, identify crabapple taxa sold, and characterize consumer preferences. They found 'Prairifire', 'Spring Snow', and 'Snowdrift' were the best-selling selections, respectively, and that 'Radiant' and 'Royalty' were most frequently mentioned as selections dropped from nursery inventories. Our study includes more states and identifies disease frequencies.

Today we are far better equipped (weather records, diagnostic tests, and breeding programs) to predict crabapple performance in regions of the United States where crabapples are utilized, but very little data exists that characterize crabapple preferences among horticulture professionals. Therefore, we developed and conducted a survey of nursery and landscape firms to identify crabapple use preferences in several regions across the United States and to determine if regional disease problems help shape crabapple inventories

\section{Materials and methods}

Audience AND REgions. Survey questionnaires were sent by first-class mail on 5 Oct. 2000 to members of either state nursery/landscape associations or the Associated Landscape Contractors of America (ALCA, Herndon, Va.) in Oregon, Washington, Colorado, Utah, Iowa, Minnesota, Missouri, Illinois, Indiana, Michigan, New York, Ohio, and Pennsylvania. These states were chosen because of the prominent role crabapples play in each of their green industries. Retail nurseries and landscape design/build firms were our intended target audience. All firms in the target audience of any one particular state received a questionnaire if the total number of listings was $\leq 100$. If the list contained $>100$ business listings, one-half of the total addresses were selected. Lawn-care firms, equipment rental and sales companies, nurseries selling only herbaceous plant materials, wholesale nurseries, mass merchandisers, and home-improvement stores were excluded from the study. Mass merchandisers and home improvement stores were not surveyed because of the seasonal personnel in their horticulture departments. In total, 1850 questionnaires were mailed, however, 40 were undeliverable because of ad- 
Table 1. Crabapple selections recommended by survey respondents in their regions for different landscape situations. Values are listed by percentage first followed by actual number of responses in parentheses. Less frequent responses have been consolidated in an "other" category. Regional response totals are listed in the last column.

\begin{tabular}{|c|c|c|c|c|c|c|}
\hline \multirow{2}{*}{$\begin{array}{l}\text { Survey question/ } \\
\text { crabapple selection }\end{array}$} & \multicolumn{6}{|c|}{ Responses (\%) by region ${ }^{\mathrm{z}}$ (no. of responses) } \\
\hline & West & West-central & Central & East-central & East & Total \\
\hline \multicolumn{7}{|l|}{ When a dwarf crabapple is needed } \\
\hline Sargent crabapple (Malus sargentii) & $51.7(15)$ & $31.0(9)$ & $24.0(25)$ & $73.3(102)$ & $58.5(65)$ & $52.4(216)$ \\
\hline 'Coralcole' & $6.8(2)$ & $6.8(2)$ & $13.4(14)$ & $2.8(4)$ & $13.5(15)$ & $8.9(37)$ \\
\hline 'Tina' & $0.0(0)$ & $6.8(2)$ & $16.3(17)$ & $7.1(10)$ & $6.3(7)$ & $8.7(36)$ \\
\hline 'Red Jade' & $0.0(0)$ & $6.8(2)$ & $0.0(0)$ & $2.1(3)$ & $6.3(7)$ & $2.9(12)$ \\
\hline Other & $41.3(12)$ & $48.2(14)$ & $46.1(48)$ & $16.8(20)$ & $15.3(17)$ & $26.9(111)$ \\
\hline$\chi^{2}=107.1(P<0.0001)$ & $\mathrm{n}=29$ & $\mathrm{n}=29$ & $\mathrm{n}=104$ & $\mathrm{n}=139$ & $\mathrm{n}=111$ & $\mathrm{n}=412$ \\
\hline \multicolumn{7}{|c|}{ When an upright or narrow crabapple is needed } \\
\hline 'Pink Spires' & $9.5(2)$ & $7.1(1)$ & $44.2(42)$ & $8.5(8)$ & $4.4(4)$ & $18.1(57)$ \\
\hline 'Red Barron' & $14.2(3)$ & $28.5(4)$ & $10.5(10)$ & $25.5(24)$ & $16.6(15)$ & $17.8(56)$ \\
\hline 'Velvetcole' & $0.0(0)$ & $0.0(0)$ & $5.2(5)$ & $5.3(5)$ & $21.1(19)$ & $9.2(29)$ \\
\hline 'Jewelcole' & $0.0(0)$ & $7.1(1)$ & $5.2(5)$ & $13.8(13)$ & $5.5(5)$ & $7.6(24)$ \\
\hline x 'Adirondack' & $19.0(4)$ & $7.1(1)$ & $4.2(4)$ & $7.4(7)$ & $3.3(3)$ & 3.7 (19) \\
\hline Other & $57.1(12)$ & $50.0(7)$ & $30.5(29)$ & $39.3(37)$ & $48.8(44)$ & $41.0(129)$ \\
\hline$\chi^{2}=123.1(P<0.0001)$ & $\mathrm{n}=21$ & $\mathrm{n}=14$ & $\mathrm{n}=95$ & $\mathrm{n}=94$ & $\mathrm{n}=90$ & $\mathrm{n}=314$ \\
\hline \multicolumn{7}{|l|}{ When size is not important } \\
\hline 'Prairifire' & $40.0(10)$ & $2.5(1)$ & $29.0(32)$ & $34.4(40)$ & $25.0(27)$ & $27.6(110)$ \\
\hline 'Snowdrift' & $8.0(2)$ & $0.0(0)$ & $4.5(5)$ & $11.2(13)$ & $12.0(13)$ & $8.2(33)$ \\
\hline × 'Spring Snow' & $0.0(0)$ & 48.7 (19) & $9.0(10)$ & $1.7(2)$ & $0.9(1)$ & $8.0(32)$ \\
\hline 'Red Splendor' & $0.0(0)$ & $0.0(0)$ & $25.4(28)$ & $0.0(0)$ & $0.0(0)$ & $7.0(28)$ \\
\hline 'Sutyzam' & $0.0(0)$ & $2.5(1)$ & $2.7(3)$ & $7.7(9)$ & $12.0(13)$ & $6.5(26)$ \\
\hline Other & $52.0(13)$ & $46.1(18)$ & $29.0(32)$ & $44.8(52)$ & $50.0(54)$ & $42.4(169)$ \\
\hline$\chi^{2}=241.6(P=0.0022)$ & $\mathrm{n}=25$ & $\mathrm{n}=39$ & $\mathrm{n}=110$ & $\mathrm{n}=116$ & $\mathrm{n}=108$ & $\mathrm{n}=398$ \\
\hline \multicolumn{7}{|c|}{ When attracting (feeding) birds is important } \\
\hline 'Jewelcole' & $15.7(3)$ & $0.0(0)$ & $7.5(7)$ & $17.3(16)$ & $24.6(20)$ & $14.8(46)$ \\
\hline 'Red Splendor' & $0.0(0)$ & $0.0(0)$ & $39.7(37)$ & $3.2(3)$ & $1.2(1)$ & $13.2(41)$ \\
\hline 'Snowdrift' & $10.5(2)$ & $12.0(3)$ & $7.5(7)$ & $7.6(7)$ & $11.1(9)$ & $9.0(28)$ \\
\hline 'Prairifire' & $15.7(3)$ & $8.0(2)$ & $8.6(8)$ & $8.6(8)$ & $8.6(7)$ & $9.0(28)$ \\
\hline 'Sutyzam' & $5.2(1)$ & $4.0(1)$ & $4.3(4)$ & $8.6(8)$ & $14.8(12)$ & $8.3(26)$ \\
\hline Other & $52.6(10)$ & $76.0(19)$ & $32.6(30)$ & $54.3(50)$ & $39.5(32)$ & $45.4(141)$ \\
\hline$\chi^{2}=128.1$ & $\mathrm{n}=19$ & $\mathrm{n}=25$ & $\mathrm{n}=93$ & $\mathrm{n}=92$ & $\mathrm{n}=81$ & $\mathrm{n}=310$ \\
\hline
\end{tabular}

${ }^{2}$ West region $=$ respondents from Oregon and Washington. West-central region $=$ respondents from Colorado and Utah. Central region $=$ respondents from Iowa, Minnesota and Missouri. East-central region = respondents from Illinois, Indiana, and Michigan. East region = respondents from Ohio, New York, and Pennsylvania

dress changes. Questionnaires included a cover letter explaining our research objectives and instructions for returning the completed questionnaire. On 19 Oct. 2000, reminder postcards were sent to individuals who had not responded.

SURVEY COMPONENETS. The questionnaire contained 21 numbered questions in closed-end (12 questions) and open-end (9 questions) form. Questions addressed: number of crabapple cultivars or species offered, crabapple selections offered for specific landscape use, crabapple traits and their relative importance, alternatives to crabapples, fruitless selections, crabapple selections eliminated from inventories, and crabapple diseases and their relative importance.

Data ANALYSIS. Responses were tabulated initially by state, combined into five regions, and analyzed. The regions and states included: west region (Oregon and Washington), westcentral region (Colorado and Utah), central region (Iowa, Minnesota, and Missouri), east-central region (Illinois, Indiana, and Michigan), and east region (New York, Ohio, and Pennsylvania). Closed-end and open-end questions were coded and tabulated. All data were tabulated and analyzed by using ProcFreq procedure in SAS (SAS Institute, Cary, N.C.). Chi-square analysis was conducted to determine whether proportions of the selections chosen by survey respondents were statistically significant between regions (Garber and Bondari, 2000). This analysis was aimed at formally testing for regional differences. Infrequently chosen responses were consolidated into an "other" category. Preference for the top taxon was estimated by the difference between the most- and the second-most frequently chosen selection.

\section{Results and discussion}

Completed questionnaires were received from 511 individuals $(28.2 \%$ response rate). Owners and nursery/ garden center managers $(74.7 \%)$ completed most of the returned questionnaires. Landscape-installation managers, assistant managers, general managers, landscape designers, landscape architects, buyers, and estimators composed the remaining respondents. States furthest from Iowa showed the lowest response rates (18.7\% west region, $23.6 \%$ east region). This may be due to less importance placed on surveys originating from the midwestern U.S. or reflect the regional importance of crabapples.

When asked to identify the number of crabapple selections they sell, most respondents $(\mathbf{5 5 . 3} \%)$ reported offering at least six crabapple selections to their customers. Few respondents (8.6\%) offered no crabapple selections.

When respondents were asked to explain the number of selections they offered, $32.6 \%$ claimed personal preference guided the size of their crabapple list. The "other" category accumulated 
Table 2. Most important crabapple traits for different clientele identified by respondents. Respondents were asked to identify specific crabapple traits they might emphasize to different retail and commercial customers. Regional response totals are listed in the last column.

\begin{tabular}{|c|c|c|c|c|c|c|}
\hline \multirow{2}{*}{$\begin{array}{l}\text { Survey } \\
\text { question }\end{array}$} & \multicolumn{6}{|c|}{ Responses (\%) by region ${ }^{z}$ (no. of responses) } \\
\hline & West & West-central & Central & East-central & East & Total \\
\hline \multicolumn{7}{|c|}{ Traits respondents emphasize to retail customers } \\
\hline Flower color & $31.0(9)$ & $52.7(19)$ & $34.7(40)$ & $29.7(36)$ & $42.2(46)$ & $36.5(150)$ \\
\hline Disease resistance & $44.8(13)$ & $13.8(5)$ & $29.5(34)$ & $39.6(48)$ & $33.9(37)$ & $33.4(137)$ \\
\hline Growth habit & $20.6(6)$ & $13.8(5)$ & $21.7(25)$ & $26.4(32)$ & $19.2(21)$ & $21.7(89)$ \\
\hline Fruit color/pe & $0.0(0)$ & $11.1(4)$ & $8.6(10)$ & $3.3(4)$ & $1.8(2)$ & $4.8(20)$ \\
\hline Environmental tolerance & $3.4(1)$ & $5.5(2)$ & $5.2(6)$ & $0.8(1)$ & $2.7(3)$ & $3.1(13)$ \\
\hline Food for wildlife & $0.0(0)$ & $2.7(1)$ & $0.0(0)$ & $0.0(0)$ & $0.0(0)$ & $0.2(1)$ \\
\hline$\chi^{2}=44.8(P<0.0001)$ & $\mathrm{n}=29$ & $\mathrm{n}=36$ & $\mathrm{n}=115$ & $\mathrm{n}=12 \mathrm{l}$ & $\mathrm{n}=109$ & $\mathrm{n}=410$ \\
\hline \multicolumn{7}{|c|}{ Survey respondents' perception of the most important crabapple trait for their retail customers } \\
\hline Flower color & $69.2(18)$ & $67.6(23)$ & $80.0(92)$ & $76.5(88)$ & $88.5(93)$ & $79.4(314)$ \\
\hline Growth habit & $15.3(4)$ & $14.7(5)$ & $9.5(11)$ & $9.5(11)$ & $5.7(6)$ & $9.3(37)$ \\
\hline sistance & $11.5(3)$ & $0.0(0)$ & $4.3(5)$ & $10.4(12)$ & $2.8(3)$ & $5.6(23)$ \\
\hline $\mathrm{r} /$ persistence & $3.8(1)$ & $17.6(6)$ & $6.0(7)$ & $3.4(4)$ & $2.8(3)$ & $5.3(21)$ \\
\hline Food for wildlife & $0.0(0)$ & $0.0(0)$ & $0.0(0)$ & $0.0(0)$ & $0.0(0)$ & $0.0(0)$ \\
\hline$\chi^{2}=41.3(P<0.0001)$ & $\mathrm{n}=26$ & $\mathrm{n}=34$ & $\mathrm{n}=115$ & $\mathrm{n}=115$ & $\mathrm{n}=105$ & $\mathrm{n}=395$ \\
\hline \multicolumn{7}{|c|}{ Respondents' perception of the most important crabapple trait of commercial customers } \\
\hline Growth habit & $41.6(10)$ & $25.7(9)$ & $36.0(36)$ & $(39)$ & $27.6(26)$ & $32.5(120)$ \\
\hline Flower color & $29.1(7)$ & $28.5(10)$ & $33.0(33)$ & $23.0(27)$ & $30.8(29)$ & $28.7(106)$ \\
\hline Disease resistance & $29.1(7)$ & $8.5(3)$ & $17.0(17)$ & $33.3(39)$ & $29.7(28)$ & $25.2(93)$ \\
\hline Envir & $0.0(0)$ & $17.1(6)$ & $6.0(6)$ & $7.6(9)$ & $6.3(6)$ & $7.3(27)$ \\
\hline Fruit color/persistence & $0.0(0)$ & $20.0(7)$ & $8.0(8)$ & $2.5(3)$ & $5.3(5)$ & $6.2(23)$ \\
\hline Food for wildlife & $0.0(0)$ & $0.0(0)$ & $0.0(0)$ & $0.0(0)$ & $0.0(0)$ & $0.0(0)$ \\
\hline$\chi^{2}=57.1(P<0.0001)$ & $\mathrm{n}=24$ & $\mathrm{n}=35$ & $\mathrm{n}=100$ & $\mathrm{n}=117$ & $\mathrm{n}=94$ & $\mathrm{n}=369$ \\
\hline
\end{tabular}

${ }^{2}$ West region $=$ respondents from Oregon and Washington. West-central region = respondents from Colorado and Utah. Central region = respondents from Iowa, Minnesota and Missouri. East-central region = respondents from Illinois, Indiana, and Michigan. East region = respondents from Ohio, New York, and Pennsylvania.

the second most responses with $25.4 \%$ citing limited selection from their distributor and lack of demand for crabapples. Presumably these respondents were offering little variety or no crabapples at all.

Next, respondents were asked to recommend specific crabapple selections for several unique landscape situations. When asked to recommend a dwarf form, study participants responded with 43 suggestions. The sargent crabapple (Malus sargentii) $(52.4 \%)$ and its cultivars 'Tina' $(8.7 \%)$ and 'Candymint' (consolidated in the "other" category with $0.7 \%$ ) were clearly favored across all regions $(61.2 \%)$ (Table 1). Respondents in the east-central region were particularly fond of sargent crabapple (73.3\%).

When asked to recommend an upright or narrow-growing form, the largest number of our respondents chose the cultivars 'Pink Spires' (18.1\%) and 'Red Barron' (17.8\%) (Table 1). However, regional differences were apparent. For example, 'Pink Spires', one of the first crabapples to bloom in spring (Fiala, 1994), was the favorite among respondents in the central region (44.2\%). 'Red Barron' was selected the most in the west-central $(28.5 \%)$ and east-central $(25.5 \%)$ regions, while 'Velvetcole' (Velvet Pillar; Simpson
Nursery, Vincennes, Ind.) was the most popular upright selection in the eastern region (21.1\%). In the western region, 'Adirondack' was mentioned most frequently (19.0\%).

When tree size is not an issue, respondents in all regions except the west-central most frequently recommend the cultivar 'Prairifire' (Table 1). 'Snowdrift', 'Spring Snow' (preferred overall in the west-central region), and 'Red Splendor' were the next most frequently recommended selections, respectively. Also noteworthy was the ranking of 'Red Splendor' second behind 'Prairifire' by respondents in the central region. The disproportionate popularity of 'Red Splendor' in the central region could be an artifact of the origin of this cultivar (Bergeson Nursery, Fertile, Minn.) or increased awareness of this selection in the region.

Survey participants identified 'Jewelcole' (Red Jewel; Cole Nursery, Painesville, Ohio) as the best crabapple for attracting birds, $(15.0 \%)$ (Table 1 ). This response is somewhat perplexing because the fruit of 'Jewelcole' are extremely persistent and do not seem to attract attention from birds. Yanny (1996) states that the fruit of all crabapple selections are not equally palatable to all birds. However, soft- ening of the fruit after frost improves their palatability to birds. Over 39\% percent of respondents either chose not to answer the question or indicated the ability of a crabapple to serve as a bird feeder was not an important selection criterion for them.

Flower, fruit, foliage color, and growth habit are examples of crabapple traits that provide interest in the landscape. When asked to name the three most important crabapple traits they emphasize when dealing with retail customers our respondents identified flower color $(36.5 \%)$ disease resistance $(33.4 \%)$, and growth habit $(21.7 \%)$ (Table 2). However, respondents in the west $(44.8 \%)$ and east-central region (39.6\%) emphasized disease resistance over flower color. Only one respondent across all regions cited food for wildlife as their number one trait emphasized to retail clients. To avoid choosing an inferior cultivar, Green (1996) suggests disease resistance, fruit persistence, and ultimate tree size should be considered before floral attributes in the selection process. However, this progression is seldom followed because of strong consumer interest in flower color (Green, 1996).

A large percentage of all respondents $(79.4 \%)$ believed flower color was the trait retail customers were 
Table 3. Small flowering trees most frequently recommended as an alternative to crabapples. Respondents were asked to list the small flowering tree they most frequently recommend to clients who oppose the use of crabapples. Infrequent responses have been consolidated in an "other" category. Regional response totals are listed in the last column.

\begin{tabular}{|c|c|c|c|c|c|c|}
\hline \multirow{2}{*}{$\begin{array}{l}\text { Alternate } \\
\text { plant }\end{array}$} & \multicolumn{6}{|c|}{ Responses (\%) by region ${ }^{\mathrm{z}}$ (no. of responses) } \\
\hline & West & West-central & Central & East-central & East & Total \\
\hline Serviceberry & $3.3(1)$ & $2.7(1)$ & $7.8(9)$ & $26.4(32)$ & $20.1(22)$ & $15.2(63)$ \\
\hline Dogwood & $23.3(7)$ & $0.0(0)$ & $3.4(4)$ & $19.0(23)$ & $24.7(27)$ & $14.8(61)$ \\
\hline Flowering cherry & $20.0(6)$ & $8.3(3)$ & $5.2(6)$ & $17.3(21)$ & $17.4(19)$ & $13.3(55)$ \\
\hline Hawthorn & $0.0(0)$ & $27.7(10)$ & $18.2(21)$ & $9.0(11)$ & $7.3(8)$ & $12.1(50)$ \\
\hline Flowering pear & $6.6(2)$ & $30.5(11)$ & $7.8(9)$ & $8.2(10)$ & $11.9(13)$ & $10.9(45)$ \\
\hline Redbud & $0.0(0)$ & $5.5(2)$ & $13.0(15)$ & $9.9(12)$ & $1.8(2)$ & $7.5(31)$ \\
\hline Japanese tree lilac & $0.0(0)$ & $0.0(0)$ & $23.4(27)$ & $1.6(2)$ & $0.9(1)$ & $7.2(30)$ \\
\hline Other & $46.6(14)$ & $25.0(9)$ & $20.8(24)$ & $8.2(10)$ & $15.5(17)$ & $17.9(74)$ \\
\hline$\chi^{2}=191.4(P<.0001)$ & $\mathrm{n}=30$ & $\mathrm{n}=36$ & $\mathrm{n}=115$ & $\mathrm{n}=121$ & $\mathrm{n}=109$ & $\mathrm{n}=412$ \\
\hline
\end{tabular}

${ }^{2}$ West region $=$ respondents from Oregon and Washington. West-central region = respondents from Colorado and Utah. Central region = respondents from Iowa, Minnesota and Missouri. East-central region = respondents from Illinois, Indiana, and Michigan. East region = respondents from Ohio, New York, and Pennsylvania .

most interested in when choosing a crabapple for the home landscape (Table 2). Respondents also sensed growth habit was more important to retail customers than disease resistance in all regions except the east-central.

In general, respondents believed their commercial clients showed the most interest in growth habit $(32.5 \%)$, flower color $(28.7 \%)$, and disease resistance $(25.2 \%)$ (Table 2). Overall, respondents perceived their commercial clients were far less enthusiastic about environmental tolerance $(7.3 \%)$, fruit color/persistence $(6.2 \%)$, and wildlife value $(0.0 \%)$ (Table 2$)$.

Resistance to using crabapples by either retail or commercial clients was anticipated because of concerns with fruit litter. We asked our survey participants to identify another small flowering tree they would recom- mend as an alternative to crabapples. Considering all regions, serviceberry (Amelanchier spp.) was the most frequently mentioned alternative (15.2\%) (Table 3). Dogwood (Cornus spp.), flowering cherry (Prunus spp.), hawthorn (Crataegus spp.), flowering pear (Pyrus spp.), and redbud (Cercis spp.) also were considered viable alternatives $(14.8 \%, 13.3 \%, 12.1 \%, 10.9 \%$, and $7.5 \%$ respectively). A disproportionate percentage of respondents from the central region $(23.4 \%)$ specified japanese tree lilac (Syringa reticulata) as the most desirable substitute for crabapples.

According to survey respondents, the popularity of fruitless crabapples among their clients is high (61.2\%). However, a substantial percentage $(38.7 \%)$, primarily from the east and east-central region said they were not popular. Respondents did not provide further insight, as this was a closeended question. Across all regions, respondents identified 'Spring Snow' $(90.1 \%)$ as the most popular fruitless crabapple.

Respondents across all regions did not consider crabapples to be short-lived landscape plants $(88.2 \%)$. However, expectations about the number of years a crabapple should live if planted on an ideal site were variable. The largest percentage (42.1\%) believed 16 to 30 years was a reasonable life span, whereas $31.9 \%$ expected crabapples to live between 31 and 40 years. Only $1.5 \%$ said crabapples would live between land 15 years.

Most respondents (59.5\%) reported they had discontinued using or carrying a crabapple selection during the past 10 years primarily due to disease problems (71.5\%) (Table 4).

Table 4. Respondents' identification of up to three discontinued crabapple selections. Less frequent responses have been condensed in an "other" category due to space constraints. Regional response totals are listed in the last column.

\begin{tabular}{|c|c|c|c|c|c|c|}
\hline \multirow{2}{*}{$\begin{array}{l}\text { Crabapple } \\
\text { selections } \\
\text { discontinued } \\
\end{array}$} & \multicolumn{6}{|c|}{ Responses (\%) by region ${ }^{z}$ (no. of responses) } \\
\hline & West & West-central & Central & East-central & East & Total \\
\hline 'Radiant' & $5.2(2)$ & $2.8(1)$ & $18.1(29)$ & $9.3(20)$ & $11.9(19)$ & $11.7(71)$ \\
\hline 'Royalty' & $2.6(1)$ & $5.7(2)$ & $7.5(12)$ & $12.1(26)$ & $6.9(11)$ & $8.5(52)$ \\
\hline 'Hopa' & $2.6(1)$ & $31.4(11)$ & $8.7(14)$ & $3.7(8)$ & $5.6(9)$ & $7.0(43)$ \\
\hline 'Indian Magic' & $2.6(1)$ & $8.5(3)$ & $7.5(12)$ & $6.0(13)$ & $6.9(11)$ & $6.6(40)$ \\
\hline 'Snowdrift' & $0.0(0)$ & $2.8(1)$ & $4.3(7)$ & $8.8(19)$ & $5.0(8)$ & $5.7(35)$ \\
\hline 'Profusion' & $7.8(3)$ & $0.0(0)$ & $1.8(3)$ & $7.9(17)$ & $3.1(5)$ & $4.6(28)$ \\
\hline 'Bechtel' & $7.8(3)$ & $22.8(8)$ & $0.6(1)$ & $3.2(7)$ & $3.7(6)$ & $4.1(25)$ \\
\hline 'Red Jade' & $7.8(3)$ & $0.0(0)$ & $1.2(2)$ & $3.2(7)$ & $5.0(8)$ & $3.3(20)$ \\
\hline 'Indian Summer' & $0.0(0)$ & $2.8(1)$ & $3.1(5)$ & $3.7(8)$ & $2.5(4)$ & $2.9(18)$ \\
\hline 'Dolgo' & $5.2(2)$ & $5.7(2)$ & $1.2(2)$ & $3.2(7)$ & $3.1(5)$ & $2.9(18)$ \\
\hline 'Branzam' & $2.6(1)$ & $0.0(0)$ & $2.5(4)$ & $2.3(5)$ & $5.0(8)$ & $2.9(18)$ \\
\hline$\times z u m i$ & $0.0(0)$ & $0.0(0)$ & $1.8(3)$ & $2.8(6)$ & $4.4(7)$ & $2.6(16)$ \\
\hline 'Thunderchild' & $0.0(0)$ & $0.0(0)$ & $7.5(12)$ & $0.4(1)$ & $0.0(0)$ & $2.1(13)$ \\
\hline $\begin{array}{l}\text { Japanese flowering crab } \\
\text { (Malus floribunda) }\end{array}$ & & & & & & \\
\hline (Malus floribunda) & $15.7(6)$ & $2.8(1)$ & $1.2(2)$ & $1.4(3)$ & $0.6(1)$ & $2.1(13)$ \\
\hline Other & $9.6(5)$ & $0.0(0)$ & $13.8(18)$ & $13.8(21)$ & $16.0(21)$ & $12.7(65)$ \\
\hline$\underline{\chi^{2}}=30.7(P=.3266)$ & $\mathrm{n}=38$ & $\mathrm{n}=35$ & $\mathrm{n}=160$ & $\mathrm{n}=214$ & $\mathrm{n}=159$ & $n=606$ \\
\hline
\end{tabular}


'Radiant' (11.7\%), 'Royalty' (8.5\%), 'Hopa' (7.0\%), 'Indian Magic' (6.6\%), and 'Snowdrift' (5.7\%) were the most commonly mentioned discontinued selections over all regions (Table 4 ). 'Radiant' and 'Royalty' ranked first or second in the central, east-central and east regions, whereas 'Hopa' was the most frequently discontinued cultivar in the west-central region. Interestingly, japanese flowering crab (M. floribunda) was the cultivar most often discontinued in the western region.

Apple scab was identified as the most prevalent crabapple disease across all regions (67.8\%) except in the westcentral region, where fire blight was considered most problematic $(80.9 \%)$. The higher frequency of fire blight is due to later blooming periods at higher elevations (Smith, 1998).

Disease resistance has been stressed more than any other topic with regard to crabapples at the university level (Iles and Stookey, 1997). However, respondents in our study believe their retail and commercial clients are more concerned with flowers and growth habit.

A promotional campaign should be modeled after the Perennial Plant Association's (PPA, Hilliard, Ohio) perennial of the year to highlight the best crabapple selections. Suggested selections may change as climactic conditions change across the United States, thus encouraging the use of the best cultivars and species available.

\section{Literature cited}

Brewer, J.E., L.P. Nichols, C.C. Powell, and E.M. Smith. 1979. The flowering crabapple-A tree for all seasons. Coop. Ext. Serv. N.E. States. NE223, NCR78.

Draper, E.A., J.A. Chatfield, and K.D. Cochran. 1996. The magic of Malus. Amer. Nurseryman 184:46-55

Fiala, J.L. 1994. Flowering crabapples: The genus Malus. Timber Press, Portland, Ore.
Garber, M.P. and K. Bondari. 2000. Selling plants through horticulture distribution centers. J. Environ. Hort. 18:179-183.

Green, T.L. 1996. Crabapples-When you're choosing one of those apple cousins, make flowers your last consideration. Amer. Horticult. 75:18-23.

Guthery, D.E. and E.R. Hasselkus. 1992. Jewels of the landscape. Amer. Nurseryman 175(1):28-41.

Hamilton, D. 1986. Supply and demand information-The most popular shade and flowering trees. Ornamentals N.W. Nwsltt. Index IV 10:8. Spring.

Iles, J.K. and J.S. Stookey. 1997. Crabapples: Sales trends and consumer preferences in Iowa. J. Arboricult. 23:94-99.

Nichols, L.P. 1985. National crabapple evaluation program. Malus 1:1-2.

Smith, E.M. 1979. A 10 year evaluation of flowering crabapple susceptibility to apple scab in Ohio, p. 36-39. In: Ornamental plants-1979: A summary of research. Ohio Agr. Res. Dev. Ctr., Res. Cir. 246.

Smith, E.M. and S.A. Treaster. 1990. Evaluation of flowering crabapple susceptibility to apple scab in Ohio-1989, p. 21-26. In: Ornamental plants: A summary of research 1990. Ohio State Univ., Ohio Agr. Res. Dev. Ctr. Spec. Circ. 135

Smith, E.M. and S.A. Treaster. 1990. Evaluation of flowering crabapple susceptibility to apple scab in Ohio-1990, p. 10-15. In: Ornamental plants: A summary of research 1990. Ohio State Univ., Ohio Agr. Res. Dev. Ctr. Spec. Circ. 137

Smith, E.M. and S.A. Treaster. 1991. Evaluation of flowering crabapple susceptibility to apple scab in Ohio-1991, p. 15-20. In: Ornamental plants: A summary of research 1990. Ohio State Univ., Ohio Agr. Res. Dev. Ctr. Spec. Circ. 140.

Smith, T. 1998. Fireblight: A 1998 Washington State perspective. Good Fruit Grower 1-7.

Yanny, M. 1996. Ornamental crabapples —For the birds. Malus 10:21-22.

\section{Profile of the Virginia Commercial Greenhouse Industry}

\author{
Holly L. Scoggins, ${ }^{1}$ \\ Joyce G. Latimer, ${ }^{2}$ and \\ Victoria T. Barden ${ }^{3}$
}

Additional INDEX WORDS. floriculture, nursery, survey

\begin{abstract}
Summary. A survey was conducted in 2000-01 to provide a comprehensive description of Virginia's commercial greenhouse industry. A total of 274 responses were analyzed. Responses were categorized based on the amount of heated greenhouse space: small, medium, large, or other (including part-time). The survey included questions about growing space, number of employees, education and experience of respondent, crops grown, gross receipts, and target markets. Seventy-five percent of the respondents were owners or owners/growers and respondents reported an average of 15 years experience. Most greenhouse operations were classified as small or less than $10,000 \mathrm{ft}^{2}\left(929.0 \mathrm{~m}^{2}\right)$. A wide variety of crops were reported, with more than $\mathbf{5 0 \%}$ growing bedding plants and nearly $50 \%$ growing herbaceous perennials in the greenhouse. Market outlets were about equally divided between wholesale and retail.
\end{abstract}

A survey of the greenhouse and perennial production segment of the ornamental horticulture industry in Virginia was developed and conducted by faculty of the Department of Horticulture at Virginia Polytechnic and State University (Virginia Tech) and faculty of the Virginia Cooperative Extension (VCE) Service with input

Department of Horticulture, Virginia Tech, Blacksburg, Virginia 24061-0327.

${ }^{1}$ Assistant professor.

${ }^{2}$ Professor and extension specialist.

${ }^{3}$ Research assistant

The research reported herein was funded in part by the Virginia Agriculture Council, the Virginia Nursery and Landscape Association and the Virginia Flower Growers Assocition. The autors graflly acknowledge the assistance of Michael Lambur and Lex Bruce, Extension Educational Programming. Mention of brands and products does not imply endorsement of this product by Virginia Tech. 